\title{
The effect of colostrum intake on blood plasma proteome profile in newborn lambs: low abundance proteins
}

\author{
Lorenzo Enrique Hernández-Castellano ${ }^{1}$, André Martinho Almeida ${ }^{2,3,4^{*}}$, Miguel Ventosa ${ }^{4}$, Ana Varela Coelho²,
} Noemí Castro ${ }^{1}$ and Anastasio Argüello ${ }^{1}$

\begin{abstract}
Background: Colostrum intake by newborn lambs plays a fundamental role in the perinatal period, ensuring lamb survival. In this study, blood plasma samples from two groups of newborn lambs (Colostrum group and Delayed Colostrum group) at 2 and $14 \mathrm{~h}$ after birth were treated to reduce the content of high abundance proteins and analyzed using Two-Dimensional Differential in Gel Electrophoresis and MALDI MS/MS for protein identification in order to investigate low abundance proteins with immune function in newborn lambs.

Results: The results showed that four proteins were increased in the blood plasma of lambs due to colostrum intake. These proteins have not been previously described as increased in blood plasma of newborn ruminants by colostrum intake. Moreover, these proteins have been described as having an immune function in other species, some of which were previously identified in colostrum and milk.

Conclusions: In conclusion, colostrum intake modified the low abundance proteome profile of blood plasma from newborn lambs, increasing the concentration of apolipoprotein A-IV, plasminogen, serum amyloid A and fibrinogen, demonstrating that colostrum is essential, not only for the provision of immunoglobulins, but also because of increases in several low abundance proteins with immune function.
\end{abstract}

\section{Background}

The relationship between colostrum intake and newborn ruminant survival has been extensively characterized [1-4]. Colostrum is the first source of nutrition in neonatal ruminants, supplying not only nutrients, but having also a fundamental biological function, promoting immunoglobulin (Ig) transfer from the dam to the newborn. Moreover, colostrum has been described as having a mixture of diverse components, such as fat, lactose, vitamins and minerals that have a high nutritional importance [5]. However, beyond the nutritional function, colostrum contains a complex mixture of proteins that actively participate in the protection of the neonate against pathogens and other post-partum environmental challenges [6].

\footnotetext{
* Correspondence: aalmeida@fmv.utl.pt

${ }^{2}$ Instituto de Tecnología Química e Biologica, Universidade Nova de Lisboa, Oeiras, Portugal

${ }^{3}$ Instituto de Investigação Científica Tropical (IICT) \& Centro Interdisciplinar de Investigação em Sanidade Animal (CIISA), Lisbon, Portugal

Full list of author information is available at the end of the article
}

To date, a wide variety of colostrum and milk bioactive peptides and proteins have not only been linked to the passive immune transfer, such as lactoferrin [7], lactoperoxidase [8] or lysozymes [9], but also promoting gastrointestinal growth and development of the newborn, such as insulin-like growth factors (IGF-1 and IGF-2) or the transforming growth factor beta (TGF-BI and TGF-B2) $[6,10]$.

As a consequence, colostrum intake and colostrum protein absorption play an essential role in passive immune transfer and ultimately in newborn survival $[11,12]$. However, the absorbance conditions for intact proteins decrease during the first $48 \mathrm{~h}$ after birth, therefore colostrum feeding must take place during this period [13]. It has been described how feeding newborn ruminants with colostrum, with a concentration of Igs that is insufficient results in high mortality rates and low productive performances, with negative consequences for the economic benefits of farmers and breeders and severe consequences to animal welfare $[14,15]$. 
Proteomics has been used to characterize protein changes in the transition from colostrum to milk in cattle [16,17]. Additionally, the study of low abundance proteins from different body fluids such as blood plasma, colostrum or milk is becoming increasingly relevant [16,18-21].

Despite the previous proteomic studies in colostrum and milk, it is still not fully known which proteins are absorbed or increased in lamb blood plasma as a result of colostrum intake. It is hypothesized that early colostrum intake modifies the proteome of newborn lamb blood plasma. For this reason, the aim of this study was to analyze blood plasma low abundance proteins from colostrum-fed lambs compared to colostrum-deprived lambs, during the first $14 \mathrm{~h}$ after birth, in order to identify these plasma protein changes. Results from this study will contribute to understand the importance of colostrum on passive immune transfer and the lamb immune system development.

\section{Results and discussion}

In this experiment we have used an approach based on the analysis of the proteome of low abundant proteins in plasma from newborn lambs using the ProteoMiner ${ }^{\oplus}$ (Bio-Rad, Hercules, CA, USA) technology that allows the removal of the higher-abundance proteins in the plasma, particularly albumin, IgG and IgM, followed by a 2-DE DIGE analysis and protein identification using mass spectrometry. With reference to this topic, many methodologies can be found in the market, however several authors have observed excellent results using ProteoMiner ${ }^{\odot}$ not only in the removal of high abundance proteins, but also in the high concentration and intensity of low abundance proteins [21,22].

During this study, no body weight differences were observed between groups (see Table 1). Moreover, no evidences of illness were detected during health status monitoring.

We evaluated the levels of IgG and IgM in nonProteoMiner ${ }^{\bullet}$ treated plasma samples in order to determine

Table 1 BW and blood plasma IgG and IgM evolution in Colostrum (C) and Delayed Colostrum (DC) groups at 2 and $14 \mathrm{~h}$ after birth

\begin{tabular}{|c|c|c|c|}
\hline & \multirow[t]{2}{*}{ Group } & \multicolumn{2}{|c|}{ Time after birth (h) } \\
\hline & & 2 & 14 \\
\hline \multirow[t]{2}{*}{ BW (kg) } & C & $4.17 \pm 0.32$ & $4.12 \pm 0.17$ \\
\hline & DC & $4.26 \pm 0.29$ & $4.18 \pm 0.34$ \\
\hline \multirow[t]{2}{*}{$\operatorname{lgG}(\mathrm{mg} / \mathrm{mL})$} & C & ND & $7.406 \pm 0.76$ \\
\hline & DC & ND & ND \\
\hline \multirow[t]{2}{*}{$\operatorname{lgM}(\mathrm{mg} / \mathrm{mL})$} & C & ND & $0.443 \pm 0.08$ \\
\hline & $D C$ & ND & ND \\
\hline
\end{tabular}

ND means No detectable; BW means Body weight; IgG means Immunoglobulin G; IgM means Immunoglobulin. the presence or absence of colostrum proteins in both groups ( $C$ group and $\mathrm{DC}$ group) at the two studied times ( 2 and $14 \mathrm{~h}$ after birth). Results are shown also in Table 1 where the concentration of the two Igs in the two studied groups ( $\mathrm{C}$ and $\mathrm{DC}$ groups) and at 2 and $14 \mathrm{~h}$ after birth is presented. At birth $(2 \mathrm{~h})$ animals from both groups had no detectable (ND) IgG concentration in blood. However, when both groups were compared at $14 \mathrm{~h}$ after birth, IgG concentration could be detected only in $\mathrm{C}$ group $(7.406 \mathrm{mg} / \mathrm{mL} v s$. ND in $\mathrm{C}$ and DC group, respectively). A similar pattern was observed when IgM concentrations were analyzed, with no detection at $2 \mathrm{~h}$ after birth in any of the experimental groups and being detected in $\mathrm{C}$ group, but not in the DC group, at $14 \mathrm{~h}$ after birth. Several authors have observed a similar evolution in Igs level, depending on the total amount of Igs present in colostrum, in newborn blood from lambs [23], calves [24,25] and goat kids [2,26]. As expected, these results confirm that the presence of colostrum IgG and IgM in the C group in blood at $14 \mathrm{~h}$ after birth is due to colostrum intake.

As shown in Figure 1, a total of 11 spots showing over-expression in lambs at $14 \mathrm{~h}$ after birth were detected in the $\mathrm{C}$ group. These spot relative intensities were similar between groups (C and DC group) at $2 \mathrm{~h}$ after birth and did not increase in the DC group at $14 \mathrm{~h}$ (Table 2). Of these 11 spots, we were able to identify a total of 7 spots, as presented in Table 3. The spots were identified as apolipoprotein A-IV (spots 563,565 and 572), plasminogen (spot 201), serum amyloid A (spot 726) and fibrinogen gamma chain (spots 475 and 490). These proteins may play an important role either in the immunesystem development or in the immune protection or even both at the early stages of life and will subsequently be described separately.

\section{Apolipoprotein A-IV (Apo A-IV)}

The metabolic function of apolipoprotein A-IV (Apo A-IV) has not been fully established, however it has been suggested that Apo A-IV plays an important role at early life, modulating the enterocyte lipid transport efficiency in fatty foods, namely colostrum [27]. For this reason, the intestinal synthesis and secretion of Apo A-IV increases during fat absorption [28]. Additionally, Apo A-IV has antioxidant properties, acts as a postprandial satiety signal, and reduces gastric acid secretion [27]. An increase in the expression of this protein in colostrum may play a role in the protection of the immunoglobulin molecule structure, reducing the gastric acid secretion in the stomach of the newborn lamb and increasing the total amount of intact Igs absorbed in the intestine.

Finally, Apo A-IV has been described as having an immunomodulatory effect against external agents (e.g. experimental induced colitis using dextran sulfate sodium) 


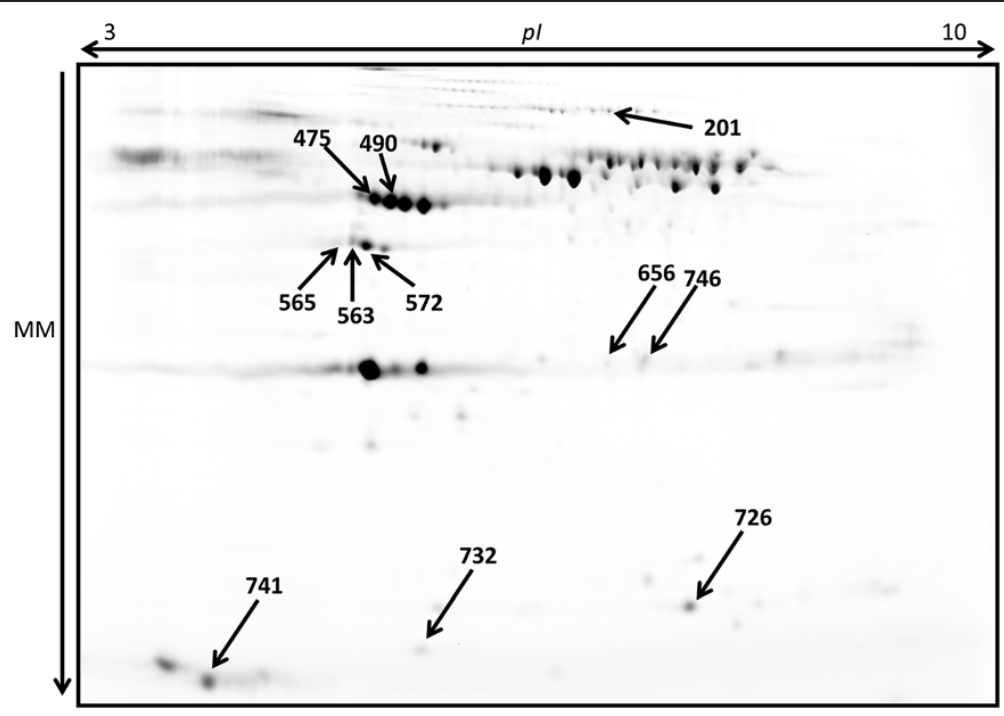

Figure 1 Lamb plasma pool labelled with Cy2 used as a reference gel in gel analysis. Protein extracts were processed using ProteoMiner ${ }^{\oplus}$ commercial kit and used in DIGE, where a total of $50 \mu \mathrm{g}$ were loaded per CyDye. Spots showing differential expression are highlighted with arrows*. pl - Isoelectric point and M - Molecular Mass. *These spots were similar between groups (C and DC group) at $2 \mathrm{~h}$ after birth and did not increase in the DC group at $14 \mathrm{~h}$. Moreover, these spots were found to increase when C and DC group were compared at $14 \mathrm{~h}$.

in mice [29]. Consequently, an increase in the blood plasma levels of Apo A-IV could also contribute to protect the newborn from infections at this early stage of life.

\section{Plasminogen (PLG)}

This glycoprotein is the precursor of plasmin, a fibrinolytic enzyme that plays an important role in the dissolution of fibrin blood clots in order to prevent thrombosis $[30,31]$. Nevertheless, this protein has been identified not only in blood, but also in colostrum and milk [32]. In bovine, sheep and goat milk, plasmin and plasminogen forms are identical to those found in blood [33].

In addition to its main role in the dissolution of fibrin blood clots, plasminogen is structurally similar to Apo A-IV [34]. Apo A-IV, as with other Apo A proteins, has the capacity to bind fibrin and proteins of endothelial cells and monocytes, and therefore may inhibit plasminogen binding and plasmin generation [35]. The presence of this protein in colostrum and the increase of this protein in blood plasma could thwart the Apo A-IV to bind fibrin in newborn lambs.

Additionally, plasminogen has immune activity, as it contributes to neutrophil migration to an infection site [36]. An increase of this protein expression in plasma promotes the neutrophil migration in blood and therefore may contribute to the immune response against potential infections in the newborn lamb. In agreement with these findings, Theodorou et al. [37] found an increase of plasminogen concentration in blood and milk during acute mastitis in lactating dairy ewes. Therefore the colostrum intake seems to be an important factor that increases plasminogen concentration in blood at this stage of life.

Plasminogen participates also in the regulation of cellular apoptosis [38], specifically the apoptosis of adherent cells induced by disruption of integrin-mediated cell-matrix interactions. This has been described under specific physiological conditions, such as the involution of the mammary gland after lactation and the renewal of intestinal epithelial cells. The apoptotic processes in the latter tissue is of important relevance in the absorption of Igs by newborn ruminants during the first hours after birth, as described by Castro-Alonso et al. [39]. Therefore, the increase of this protein in blood may delay the decrease of the apoptosis rate of intestinal epithelial cells during the early stage of life, increasing the available time for colostrum components absorption, including both Igs and other proteins.

\section{Serum amyloid a (SAA)}

Serum Amyloid A (SAA) is normally found in different isoforms and complexes with lipoproteins, while its plasma concentration vary depending on the species [40]. It is an apolipoprotein that takes part in the acute phase of inflammation [41-43] and represents one of the most conserved proteins among mammals supporting the premise that it has a basic and essential role in the innate immune system. However, this protein has also been identified in colostrum of several species, such as human [44], horse, cattle and sheep [45,46]. The importance of it in inflammatory processes has been fully monitored, showing 
Table 2 Spots showing differential expression between at least two experimental groups $(p<0.05$ and fold $>1.3)$

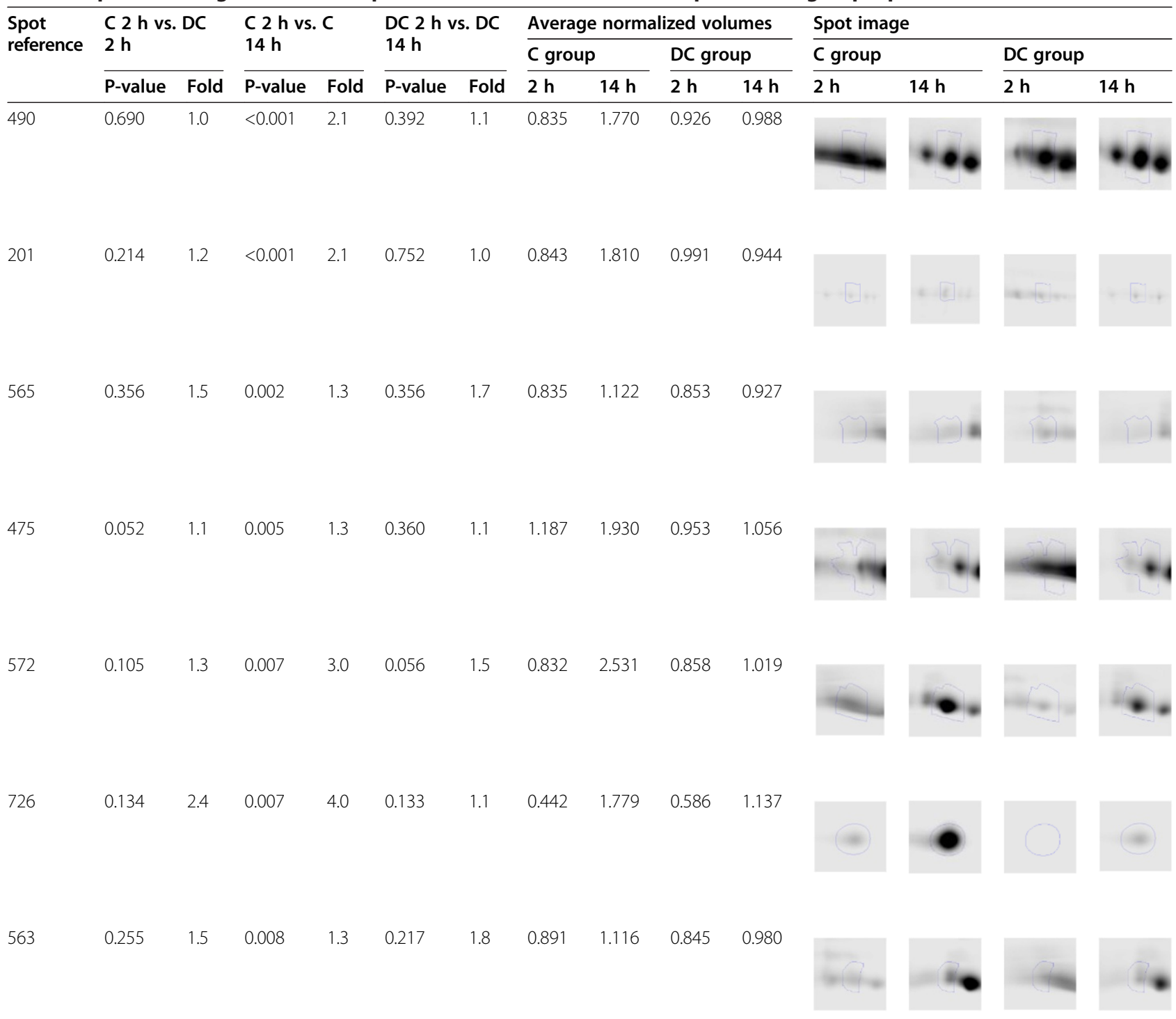

$\mathrm{C} 2 \mathrm{~h}$ and DC $2 \mathrm{~h}$ means Colostrum group and Delayed Colostrum group at $2 \mathrm{~h}$ after birth, respectively; $\mathrm{C} 14 \mathrm{~h}$ and DC $14 \mathrm{~h}$ means Colostrum group and Delayed Colostrum group at $14 \mathrm{~h}$ after birth.

Table 3 Mass spectrometry identification of differentially expressed proteins from lamb plasma

\begin{tabular}{|c|c|c|c|c|c|c|c|c|}
\hline \multirow{2}{*}{$\begin{array}{l}\text { Spot } \\
\text { reference }\end{array}$} & \multirow[t]{2}{*}{ Protein name } & \multirow{2}{*}{$\begin{array}{l}\text { Accession } \\
\text { number }\end{array}$} & \multirow{2}{*}{$\begin{array}{l}\text { Theoretical molecular } \\
\text { mass }(\mathrm{kDa})\end{array}$} & \multirow{2}{*}{$\begin{array}{l}\text { Theoretical } \\
\text { PI }\end{array}$} & \multicolumn{2}{|c|}{ Matched peptides $^{a}$} & \multirow{2}{*}{ 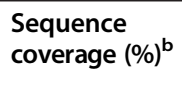 } & \multirow{2}{*}{$\begin{array}{l}\text { Protein } \\
\text { score }^{c}\end{array}$} \\
\hline & & & & & $\overline{M S}$ & MS/MS & & \\
\hline 490 & Fibrinogen gamma-B chain & FIBG_BOVIN & 50.8 & 5.5 & 7 & 5 & 16 & 361 \\
\hline 201 & Plasminogen (Fragment) & PLMN_SHEEP & 38.6 & 7.5 & 7 & - & 23 & 86 \\
\hline 565 & Apolipoprotein A-IV & APOA4_BOVIN & 42.9 & 5.3 & 12 & 1 & 26 & 183 \\
\hline 475 & Fibrinogen gamma-B chain & FIBG_BOVIN & 50.8 & 5.5 & 8 & 4 & 15 & 332 \\
\hline 572 & Apolipoprotein A-IV & APOA4_BOVIN & 42.9 & 5.3 & 17 & 8 & 35 & 738 \\
\hline 726 & Serum amyloid $\mathrm{A}$ & SAA_BOVIN & 14.5 & 7.8 & 4 & 1 & 30 & 62 \\
\hline 563 & Apolipoprotein A-IV & APOA4_BOVIN & 42.9 & 5.3 & 15 & 1 & 35 & 432 \\
\hline
\end{tabular}

${ }^{a}$ Number of peptides, matching the identified protein, whose sequence differs in at least one amino acid residue; ${ }^{\mathrm{b}}$ Percentage of the identified protein sequence covered by the matched peptides; ' Identification Score obtained with the Mowse algorithm. A result is considered to be significant when a score above 61 is attained. 
that the circulating concentration of SAA protein is increased by 1000 -fold within 24 to $48 \mathrm{~h}$ after infection/ inflammation from a basal level of $0.82 \pm 0.53 \mu \mathrm{g} / \mathrm{mL}$ [47].

The SAA protein has numerous pro-inflammatory actions: it works as a chemoattractant to neutrophils, monocytes, and T lymphocytes, causing leukocyte infiltration and promoting neutrophil adhesion to endothelial cells [48-50], stimulating neutrophils and monocytes to release not only cytokines [51,52], but also matrix metalloproteinases [53]. According to $\mathrm{He}$ et al. [54], these findings suggest a key function for SAA not only in the establishment, but also in the maintenance of inflammation, meaning that newborn lambs fed with colostrum at this early stage of life reportedly have a clear advantage, increasing this protein level in blood, and consequently producing a more efficient immune status.

\section{Fibrinogen gamma chain (FGG)}

The fibrinogen gamma chain (FGG) is one of the three components of fibrinogen which is the precursor of fibrin, the most abundant component in blood clots. However, this protein also has a defensive function, having been demonstrated that fibrinogen concentration increases during acute-phase reactions [55,56]. Moreover, Yamada et al. [57] studied differences in low abundance proteins between bovine colostrum and milk, showing that some of them were only present in colostrum, such as fibrinogen, which could explain the plasma increase of this protein in animals that were fed with it. Additionally, several authors have described that fibrinogen can bind to integrins $[58,59]$, that are normally expressed

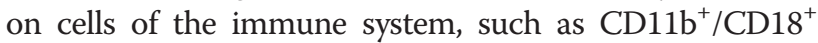
monocytes. The $\mathrm{CD}_{11} \mathrm{~b}^{+} / \mathrm{CD} 18^{+}$integrin receptor $(\alpha \mathrm{M} \beta 2$, Mac-1, complement receptor 3 ) is a member of the $\beta 2$ integrin family, which is in turn expressed on monocytes and macrophages. When fibrinogen binds to $\mathrm{CD}_{11 b^{+}} / \mathrm{CD} 18^{+}$, integrin causes an extensive array of cell signaling responses, namely the activation of the nuclear factor kappa-light-chain-enhancer of activated B cells $(\mathrm{NF}-\mathrm{kB})$ and mitogen-activated protein kinase (MAPK)/ phosphatidylinositol 3-kinase (PI3K). This data indicates that fibrinogen can function not only as a substrate in the clotting cascade, but also as an important effector during the evolution of the innate immune response [60]. Therefore, intake of colostrum and the subsequent increase of fibrinogen in lamb blood plasma may benefit the newborn immune system efficiency.

\section{Conclusions}

In conclusion, early colostrum intake produced an increase of non-immunoglobulin proteins in lamb blood plasma, such as apoliprotein A-IV, plasminogen, serum amyloid $\mathrm{A}$ and fibrinogen. These proteins have reported immune functions in other species, suggesting that colostrum provides not only Igs, but also nonimmunoglobulin proteins. These proteins play a fundamental role in the activation and attraction of immune cells, the apoptosis rate of the enterocytes and the low gastric secretion, among other roles. The results of this work contribute information about proteins with immune function that are increased after colostrum intake. High plasma concentrations of these proteins may decrease lamb mortality and increase the economic benefit for farmers. In the future, further proteomic studies will be necessary in order to increase the general knowledge about the role of colostrum in the passive immune transfer. Such studies could consist in the fully qualitative characterization of proteins present in colostrum, as well as samples from C and DC group at 2, 14 and $26 \mathrm{~h}$. Moreover, a quantitative study could be performed on samples from both groups (C and DC group) at 2, 14 and $26 \mathrm{~h}$ in order to detect if lambs, receiving a delayed colostrum meal $(14 \mathrm{~h})$ are able to reach a similar protein concentration than lambs fed with colostrum after birth $(2 \mathrm{~h})$ at $26 \mathrm{~h}$ after birth.

\section{Methods}

The experiment was approved by the ethics committee of the Faculty of Veterinary of the Universidad de Las Palmas de Gran Canaria.

\section{Samples collection}

The Canarian dairy sheep breed was used for this experiment. This breed is a high yield dairy breed $(1.8 \mathrm{~L} / \mathrm{d})$ with a lactation period of 180-200 days [61]. Ewes were fed with corn, soy 44 (crude protein 44 per cent), dehydrated lucerne, dehydrated beetroot, lucerne hay and a vitamin-mineral supplement in accordance with the guidelines issued by the Institut Nationale de la Recherche Agronomique (Paris, France) [62]. Two groups of 6 newborn male lambs each from single births were used in this experiment. The experiment took place at the experimental farm of the Veterinary Faculty of the Universidad de Las Palmas de Gran Canaria (Canary Islands, 28 $8^{\prime}$ 20.66" N, $15^{\circ} 30^{\prime} 24.97^{\prime \prime} \mathrm{W}$, Spain) in spring. Animals were fed with sheep colostrum at different time points. One group (termed Colostrum group; $\mathrm{C}$ group) received two colostrum meals, at 2 and $14 \mathrm{~h}$ after birth. The other group (termed Delayed Colostrum group; DC group) was not fed with colostrum at $2 \mathrm{~h}$ after birth, but received one colostrum meal at $14 \mathrm{~h}$ after birth in order to ensure the survival of these animals.

Comparative analysis of different fluids (such as colostrum and plasma samples) using 2-D gels is not meaningful. Instead one group did not receive colostrum (DC group) during the experimental period (from birth to 14 hours after birth before feeding). Plasma from this group without colostrum proteins was compared with 
plasma from lambs that received a colostrum meal (C group) at 2 hours after birth. In order to ensure the survival of lambs, each animal (from both groups) was also fed at $24 \mathrm{~h}$ after birth. The total volume of colostrum was equivalent to $4 \mathrm{~g}$ of $\mathrm{IgG} / \mathrm{kg}$ of BW as previously suggested in colostrum immune studies [26,63].

The colostrum source was from a frozen pool with containing Immunoglobulin G (IgG) at a concentration of $64.74 \mathrm{mg} / \mathrm{mL}$. Blood samples from both groups were collected before feeding at 2 and $14 \mathrm{~h}$ after birth. The only difference between the groups was the colostrum administration at $2 \mathrm{~h}$ after birth. Tubes with $\mathrm{K}$ - ethylenediaminetetraacetic acid (EDTA) were used for blood sampling. After centrifugation, the plasma sample was frozen at $-80^{\circ} \mathrm{C}$ until further analysis. During this experiment, lambs were accommodated in artificial rearing rooms, providing at least $0.3 \mathrm{~m}^{2}$ floor space per lamb. Each room had central heating conferring a room temperature of approximately $20^{\circ} \mathrm{C}$ and followed standard commercial procedures used in the Canary Islands.

Blood Plasma IgG and IgM was analysed to determine the presence of colostrum proteins in lamb plasma from both groups ( $\mathrm{C}$ group and DC group) at the two studied times ( 2 and $14 \mathrm{~h}$ after birth). To determine plasma IgG and IgM concentration, a commercial ELISA kit (Bethyl Laboratories, Montgomery, TX, USA) was used, setting a purified sheep IgG and IgM as standard reference.

Statistical analyses of IgG and IgM were performed using SAS, Version 9.00 (SAS Institute Inc., Cary, NC). The SAS PROC MIXED procedure for repeated measurements was used to evaluate the effect of colostrum intake (C group vs. DC group) at 2 and $14 \mathrm{~h}$ after birth. A Bonferroni's test was used to evaluate differences between groups.

\section{Animal weighting and health status}

Lambs were weighed on a digital scale before each blood extraction (2 and $14 \mathrm{~h}$ after birth). Animal health status was monitored during the experimental period (for diarrhea, parasites or fever) and animals were found to be healthy throughout the experimental period.

\section{Sample treatment for analysis}

The proteomic assays were carried out at the Instituto de Tecnología Química e Biológica (Oeiras, Portugal). In order to reduce the high-abundance proteins present in blood plasma (albumin and immunoblogulins), plasma samples $(200 \mu \mathrm{L})$ were processed with a Protein Enrichment Kit (ProteoMiner ${ }^{\bullet}$ Bio-Rad, Hercules, CA, USA) following the manufacturer's instructions. Samples were subsequently desalted with $2 \mathrm{D}$-Clean-up ${ }^{\oplus}$ kit (GE Healthcare, Piscataway, NJ, USA) and quantified with 2D-Quant ${ }^{\oplus}$ kit (GE Healthcare, Piscataway, NJ, USA) following manufacturer's instructions.
Two-dimensional differential in Gel electrophoresis (DIGE) For each DIGE gel, $50 \mu \mathrm{g}$ of each treated sample was labelled with Cy3 or Cy5 cyanine dyes (GE Healthcare, Piscataway, NJ, USA), whilst the internal standard pool, created from an equal amount of protein from each studied sample, was labelled with Cy2 dye (see Additional file 1). After labelling, samples were mixed with $7 \mathrm{M}$ urea, $2 \mathrm{M}$ thiourea, 4\% (w/v) CHAPS, 2\% (w/v) DTT , 2\% (v/v) ampholytes and $0.04 \%$ bromophenol blue solution (1\%) up to a final volume of $150 \mu \mathrm{L}$. Immobiline DryStrips $\mathrm{pH}$ 3-10 and 24 cm length (GE Healthcare, Piscataway, NJ, USA) were passively rehydrated with $450 \mu \mathrm{L}$ of rehydration buffer (7 M urea, $2 \mathrm{M}$ thiourea, 4\% (w/v) CHAPS and $0.04 \%$ bromophenol blue solution (1\%)) for $6 \mathrm{~h}$ at room temperature. Isoelectric focusing was performed with an Ettan IPGphor 3 Isoelectric Focusing System coupled to a Manifold strip holding system (GE Healthcare, Piscataway, NJ, USA) following the program: $150 \mathrm{~V}$ for $3 \mathrm{~h}, 300 \mathrm{~V}$ for $3 \mathrm{~h}$, a gradient of $1000 \mathrm{~V}$ for $6 \mathrm{~h}$, a gradient of $10.000 \mathrm{~V}$ for $1 \mathrm{~h}$ and $10.000 \mathrm{~V}$ for $3 \mathrm{~h}$. Subsequently, strips were equilibrated with $50 \mathrm{mM}$ Tris- $\mathrm{HCl}$ $\mathrm{pH}$ 8.8, $6 \mathrm{M}$ urea, 30\% (v/v) glycerol, 2\% (w/v) SDS and $0.02 \%$ bromophenol blue solution (1\%), in two steps of 15 min with $1 \%(\mathrm{w} / \mathrm{v})$ DTT and $2.5 \%(\mathrm{w} / \mathrm{v})$ iodoacetamide, respectively.

After equilibration, proteins were separated in the second dimension using $12.5 \%$ polyacrylamide gels on an Ettan Dalt Six electrophoresis system (GE Healthcare, Piscataway, NJ, USA) using the running conditions recommended by the manufacturer $(1 \mathrm{~W} /$ gel for $1 \mathrm{~h}$ and $2 \mathrm{~W} /$ gel for $14-16 \mathrm{~h}$ at $12^{\circ} \mathrm{C}$ ) and using low-florescence glass plates.

Each DIGE gel was scanned with a Fluorescent Image Analyzer (Fujifilm FLA-5100, Fujifim, Tokyo, Japan), using preferred excitation/emission wavelengths for Cy2, Cy3, and Cy5 of 488/520, 532/580, and 633/670 nm, respectively, generating images that were used in gel analysis.

\section{Image analysis}

In order to detect differentially expressed proteins, gels were analysed using Progenesis SameSpots software (Nonlinear Dynamics, Newcastle upon Tyne, UK) following the manufacturer's instructions for DIGE gels. Spots with $\mathrm{p}<0.05$ and an intensity of at least 1.3 fold higher were considered to have significantly different expression levels.

\section{Visible gel staining, spot excision and digestion}

In order to excise the selected spots, DIGE gels were stained with Coomassie Brilliant Blue G-250 as previously described [64]. Spots were then manually excised for individual in-gel digestion using trypsin [64]. Briefly, spots were washed with $30 \mu \mathrm{L}$ of water for 30 minutes, washed in acetonitrile (50\%), reduced with $10 \mathrm{mM}$ DTT 
at $56^{\circ} \mathrm{C}$ for 45 minutes, alkylated with $55 \mathrm{mM}$ iodoacetamide for 30 minutes, washed in acetonitrile (100\%) and vacuum dried (SpeedVac ${ }^{\oplus}$, Thermo Fisher Scientific, Waltham, MA, USA). Gel pieces were rehydrated with a digestion buffer (50 $\mathrm{mM} \mathrm{NH}_{4} \mathrm{HCO}_{3}$ buffer) containing trypsin (Promega, Madison, WI, USA) and incubated overnight at $37^{\circ} \mathrm{C}$. The digestion buffer containing peptides was acidified with formic acid, desalted and concentrated using C8 microcolumns (POROS R2 ${ }^{\circ}$, Applied Biosystems, Foster City, CA, USA), as described [64].

\section{Protein identification}

Protein identification was conducted as described [65]. Briefly, protein identification was conducted using MALDITOF-TOF data acquired with an Applied Biosystem 4800 Proteomics Analyzer (Applied Biosystems, Foster City, CA, USA) in both MS and MS/MS mode. Positively charged ions were analysed in the reflectron mode over the $\mathrm{m} / \mathrm{z}$ range of $800-3500 \mathrm{Da}$. Each MS spectrum was obtained in a result independent acquisition mode with a total of 800 laser shots per spectra and a fixed laser intensity of $3500 \mathrm{~V}$, being externally calibrated using desArg-Bradykinin (904.468 Da), angiotensin 1 (1296.685 Da), Glu-Fibrinopeptide B (1570.677 Da), ACTH (1-17) (2093.087 Da), and ACTH (18-39) (2465.199) (Calibration Mix from Applied Biosystems). Fifteen best precursors from each MS spectrum were selected for MS/MS analysis. MS/MS analyses were performed using CID (Collision Induced Dissociation) assisted with air, using a collision energy of $1 \mathrm{kV}$ and a gas pressure of $1 \times 106$ Torr. Two thousand laser shots were collected for each MS/MS spectrum using a fixed laser intensity of $4500 \mathrm{~V}$. The $\mathrm{S} / \mathrm{N}$ ratio was set at 20 as recommended by manufacturer. Raw data was generated by the 4000 Series Explorer Software v3.0 RC1 (Applied Biosystems, Foster City, CA, USA) and all contaminant $\mathrm{m} / \mathrm{z}$ peaks originating from human keratin, trypsin autodigestion, or matrix were included in the exclusion list used to generate the peptide mass list used in the database search.

The generated mass spectra were used to search the NCBI predicted protein database, setting a taxonomical restriction (mammal database). Searches were conducted using Mowse from MASCOT-demon 2.1.0 Software (Matrix-Science) algorithm. Protein identifications were accepted if protein score was above a threshold of $95 \%$ $(\mathrm{p}<0.05)$. The interpretation of the combined MS + MS/ MS data was carried out using the GPS Explorer Software (Version 3.5, Applied Biosystems, Foster City, CA, USA), using the following parameters: missed-cleavage, one; peptide tolerance, $50 \mathrm{ppm}$; fragment mass tolerance, $0.25 \mathrm{Da}$; fixed modification, carbamidomethylation of cysteine; and variable modification, methionine oxidation. From the predicted protein database, the theoretical molecular mass and pI of the identified proteins was obtained using the Expasy Mw/pI Tool (http://www. expasy.org/tools/pi_tool.html). The identified proteins were only considered if a MASCOT protein score above $61(\mathrm{p}<0.05)$ was obtained.

\section{Additional file}

Additional file 1: DIGE experimental design. A means Colostrum group at 2 hours after birth; B means Colostrum group at 14 hours after birth; X means Delayed Colostrum group at 2 hours after birth; Z means Delayed Colostrum group at 14 hours after birth. Animals from Colostrum group were numbered from 1 to 6 . Animals from Delayed Colostrum group were numbered from 7 to 12 .

\section{Competing interest}

The authors declare that they have no competing interests.

\section{Authors' contributions}

LEHC carried out all sample collection and experimental work and wrote the manuscript. AMA and AVC coordinated and supervised all proteomic assays and manuscript preparation. MV carried protein identifications. NC supervised and advised on scientific content of the manuscript and critical revision of the text. AA designed, coordinated and supervised the study and manuscript preparation. All authors read and approved the final manuscript.

\section{Acknowledgements}

Author L.E. Hernández-Castellano, acknowledges financial support from the Formación del Profesorado Universitario (FPU) program (Ministry of Education, Madrid, Spain). The support from a Ciência 2007 research contract and grant SFRH/BPD/90916/2012 (author A.M. Almeida) and Program \# PEst-OE/EQB/ LA0004/2011 (ITQB/UNL), all from Fundação para a Ciência e a Tecnologia (Lisbon, Portugal) is acknowledged. Authors are members of the international consortium COST action FA1002: Farm Animals Proteomics (www-COST-FAProteomics.org) funded by the European Science Foundation (Brussels, Belgium) to whom network support is acknowledged. Authors finally acknowledge Jeffrey Plowman (AgResearch, Lincoln, New Zealand) for the kind English-editing of this manuscript.

\section{Author details}

${ }^{1}$ Department of Animal Science, Universidad de Las Palmas de Gran Canaria, Arucas, Gran Canaria, Spain. ${ }^{2}$ Instituto de Tecnología Química e Biologica, Universidade Nova de Lisboa, Oeiras, Portugal. ${ }^{3}$ Instituto de Investigação Científica Tropical (IICT) \& Centro Interdisciplinar de Investigação em Sanidade Animal (CIISA), Lisbon, Portugal. ${ }^{4}$ Instituto de Biologia Experimental e Tecnológica, Oeiras, Portugal.

Received: 31 October 2013 Accepted: 26 March 2014

Published: 5 April 2014

\section{References}

1. Argüello A, Castro N, Capote J, Tyler JW, Holloway NM: Effect of colostrum administration practices on serum lgG in goat kids. Livest Prod Sci 2004, 90:235-239.

2. Castro N, Capote J, Alvarez S, Arguello A: Effects of lyophilized colostrum and different colostrum feeding regimens on passive transfer of immunoglobulin g in Majorera goat kids. J Dairy Sci 2005, 88:3650-3654.

3. Castro N, Capote J, Bruckmaier RM, Arguello A: Management effects on colostrogenesis in small ruminants: a review. J Appl Anim Res 2011, 39:85-93.

4. Castro N, Capote J, Morales-Delanuez A, Rodriguez C, Arguello A: Effects of newborn characteristics and length of colostrum feeding period on passive immune transfer in goat kids. J Dairy Sci 2009, 92:1616-1619.

5. Ontsouka CE, Bruckmaier RM, Blum JW: Fractionized milk composition during removal of colostrum and mature milk. J Dairy Sci 2003, 86:2005-2011

6. Bendixen E, Danielsen M, Hollung K, Gianazza E, Miller I: Farm animal proteomics - a review. J Proteomics 2011, 74:282-293. 
7. Groves ML: The isolation of a red protein from Milk2. J Am Chem Soc $1960,82: 3345-3350$

8. Paulik S, Slanina L, Polacek M: [Lysozyme in the colostrum and blood of calves and dairy cows]. Vet Med (Praha) 1985, 30:21-28.

9. Reiter B: The lactoperoxidase-thiocyanate-hydrogen peroxide antibacterium system. In Oxigen Free Radicals and Tissue Damage (Ciba Foundation Symp) Volume 65. Edited by Excepta Medica. Amsterdam, Oxford, New York; 1979:285-294.

10. Pakkanen R, Aalto J: Growth factors and antimicrobial factors of bovine colostrum. Int Dairy J 1997, 7:285-297.

11. Stelwagen K, Carpenter E, Haigh B, Hodgkinson A, Wheeler $\Pi$ : Immune components of bovine colostrum and milk. J Anim SCi 2009, 87:3-9.

12. Danielsen $M$, Pedersen $L J$, Bendixen $E$ : $A n$ in vivo characterization of colostrum protein uptake in porcine gut during early lactation. $J$ Proteomics 2011, 74:101-109.

13. Moore M, Tyler JW, Chigerwe M, Dawes ME, Middleton JR: Effect of delayed colostrum collection on colostral lgG concentration in dairy cows. Javma-J Am Vet Med A 2005, 226:1375-1377.

14. Nowak R, Poindron P: From birth to colostrum: early steps leading to lamb survival. Reprod Nutr Dev 2006, 46:431-446.

15. Ahmad R, Khan A, Javed MT, Hussain I: The level of immunoglobulins in relation to neonatal Lamb mortality in Pak-Karakul sheep. Vet Arhiv 2000 70:129-139.

16. Reinhardt TA, Lippolis JD: Developmental changes in the milk fat globule membrane proteome during the transition from colostrum to milk. J Dairy Sci 2008, 91:2307-2318.

17. Nissen A, Bendixen E, Ingvartsen KL, Rontved CM: In-depth analysis of low abundant proteins in bovine colostrum using different fractionation techniques. Proteomics 2012, 12:2866-2878.

18. Reinhardt TA, Lippolis JD: Bovine milk fat globule membrane proteome. J Dairy Res 2006, 73:406-416.

19. Reinhardt TA, Lippolis JD, Nonnecke BJ, Sacco RE: Bovine milk exosome proteome. J Proteomics 2012, 75:1486-1492.

20. Roncada P, Piras C, Soggiu A, Turk R, Urbani A, Bonizzi L: Farm animal milk proteomics. J Proteomics 2012, 75:4259-4274.

21. Marco-Ramell A, Bassols A: Enrichment of low-abundance proteins from bovine and porcine serum samples for proteomic studies. Res Vet Sci 2010, 89:340-343.

22. Boschetti $E$, Righetti PG: The ProteoMiner in the proteomic arena: $A$ non-depleting tool for discovering low-abundance species. J Proteomics 2008, 71:255-264.

23. Halliday R, Williams MR: Absorption of inmunoglobulin from colostrum by bottle-fed lambs. Ann Rech Vet 1979, 10:549-556.

24. Muller LD, Ellinger DK: Colostral immunoglobulin concentrations among breeds of dairy-cattle. J Dairy Sci 1981, 64:1727-1730.

25. Stott $\mathrm{GH}$, Fellah A: Colostral immunoglobulin absorption linearly related to concentration for calves. J Dairy Sci 1983, 66:1319-1328.

26. Rodríguez C, Castro N, Capote J, Morales-delaNuez A, Moreno-Indias I, Sanchez-Macias D, Arguello A: Effect of colostrum immunoglobulin concentration on immunity in Majorera goat kids. J Dairy Sci 2009, 92:1696-1701

27. Stan S, Delvin E, Lambert M, Seidman E, Levy E: Apo A-IV: an update on regulation and physiologic functions. Bba-Mol Cell Biol L 2003, 1631:177-187

28. Simon T, Cook VR, Rao A, Weinberg RB: Impact of murine intestinal apolipoprotein A-IV expression on regional lipid absorption, gene expression, and growth. J Lipid Res 2011, 52:1984-1994.

29. Vowinkel T, Mori M, Krieglstein CF, Russell J, Saijo F, Bharwani S, Turnage RH, Davidson WS, Tso P, Granger DN, Kalogeris TJ: Apolipoprotein A-IV inhibits experimental colitis. J Clin Invest 2004, 114:260-269.

30. Ogiwara K, Nogami K, Nishiya K, Shima M: Plasmin-induced procoagulant effects in the blood coagulation: a crucial role of coagulation factors $\mathrm{V}$ and VIII. Blood Coagul Fibrin 2010, 21:568-576.

31. Booth NA, Bachmann F: Plasminogen-plasmin system. In Hemostasis and Thrombosis. Edited by Colman RW. Philadelphia, PA: Lippincott Williams \& Wilkins; 2006.

32. Dupont $\mathrm{D}$, Remond $\mathrm{B}$, Collin JC: ELISA determination of plasmin and plasminogen in milk of individual cows managed without the dry period. Milchwissenschaft 1998, 53:66-69.
33. Rebucci R, Fusi E, Pecorini C, Pinotti L, Cheli F, Baldi A: Evaluation of the biological activation of plasmin plasminogen system in sheep and goat milk. Ital J Anim Sci 2005, 4:330-332.

34. Feric NT, Boffa MB, Johnston SM, Koschinsky ML: Apolipoprotein(a) inhibits the conversion of Glu-plasminogen to Lys-plasminogen: a novel mechanism for lipoprotein(a)-mediated inhibition of plasminogen activation. J Thromb Haemost 2008, 6:2113-2120.

35. Rouy D, Koschinsky ML, Fleury V, Chapman J, Angles-Cano E: Apolipoprotein(a) and plasminogen interactions with fibrin: a study with recombinant apolipoprotein(a) and isolated plasminogen fragments. Biochemistry 1992, 31:6333-6339.

36. Renckens R, Roelofs JJTH, Florquin S, van der Poll T: Urokinase-type plasminogen activator receptor plays a role in neutrophil migration during lipopolysaccharide-induced peritoneal inflammation but not during Escherichia coli-induced peritonitis. J Infect Dis 2006, 193:522-530.

37. Theodorou G, Daskalopoulou M, Chronopoulou R, Baldi A, Dell'Orto V, Politis I: Acute mastitis induces upregulation of expression of plasminogen activatorrelated genes by blood monocytes and neutrophils in dairy ewes. Vet Immunol Immunop 2010, 138:124-128.

38. O'Mullane MJ, Baker MS: Elevated plasminogen receptor expression occurs as a degradative phase event in cellular apoptosis. Immunol Cell Biol 1999, 77:249-255.

39. Castro-Alonso A, Castro N, Capote J, Morales-DelaNuez A, Moreno-Indias I, Sanchez-Macias D, Herraez P, Argullo A: Short communication: apoptosis regulates passive immune transfer in newborn kids. J Dairy Sci 2008, 91:2086-2088

40. Uhlar CM, Whitehead AS: Serum amyloid A, the major vertebrate acute-phase reactant. Eur J Biochem 1999, 265:501-523.

41. Eckersall PD, Young FJ, Nolan AM, Knight CH, McComb C, Waterston MM, Hogarth CJ, Scott EM, Fitzpatrick JL: Acute phase proteins in bovine milk in an experimental model of Staphylococcus aureus subclinical mastitis. J Dairy Sci 2006, 89:1488-1501.

42. Pyorala S, Hovinen M, Simojoki H, Fitzpatrick J, Eckersall PD, Orro T: Acute phase proteins in milk in naturally acquired bovine mastitis caused by different pathogens. Vet Rec 2011, 168:535.

43. Soler L, Molenaar A, Merola N, Eckersall PD, Gutierrez A, Ceron Jل Mulero V, Niewold TA: Why working with porcine circulating serum amyloid $A$ is a pig of a job. J Theor Biol 2013, 317:119-125.

44. Kumon Y, Yasuoka Y, Yamanaka S, Wada A, Takeuchi H, Sugiura T: Acutephase serum amyloid $\mathrm{A}$ is present in human colostrum and milk. Amyloid Int J Exp Clin Investig Offic J Int Soc Amyloid 2011, 18(Suppl 1):11-13.

45. McDonald TL, Larson MA, Mack DR, Weber A: Elevated extrahepatic expression and secretion of mammary-associated serum amyloid A 3 (M-SAA3) into colostrum. Vet Immunol Immunop 2001, 83:203-211.

46. Le A, Barton LD, Sanders JT, Zhang Q: Exploration of bovine milk proteome in colostral and mature whey using an ion-exchange approach. J Proteome Res 2010, 10:692-704.

47. Wells B, Innocent GT, Eckersall PD, McCulloch E, Nisbet AJ, Burgess ST: Two major ruminant acute phase proteins, haptoglobin and serum amyloid $A$, as serum biomarkers during active sheep scab infestation. Vet Res 2013, 44:103.

48. Badolato R, Wang JM, Murphy WJ, Lloyd AR, Michiel DF, Bausserman LL, Kelvin DJ, Oppenheim JJ: Serum amyloid A is a chemoattractant: induction of migration, adhesion, and tissue infiltration of monocytes and polymorphonuclear leukocytes. J Exp Med 1994, 180:203-209.

49. Xu L, Badolato R, Murphy WJ, Longo DL, Anver M, Hale S, Oppenheim JJ, Wang JM: A novel biologic function of serum amyloid A. Induction of T lymphocyte migration and adhesion. J Immunol 1995, 155:1184-1190.

50. Su SB, Gong W, Gao JL, Shen W, Murphy PM, Oppenheim JJ, Wang JM: A seven-transmembrane, $G$ protein-coupled receptor, FPRL1, mediates the chemotactic activity of serum amyloid $A$ for human phagocytic cells. J Exp Med 1999, 189:395-402

51. He R, Sang H, Ye RD: Serum amyloid A induces IL-8 secretion through a G protein-coupled receptor, FPRL1/LXA4R. Blood 2003, 101:1572-1581.

52. Furlaneto CJ, Campa A: A novel function of serum amyloid $A$ : a potent stimulus for the release of tumor necrosis factor-alpha, interleukin-1beta, and interleukin- 8 by human blood neutrophil. Biochem Bioph Res Co 2000, 268:405-408.

53. Lee HY, Kim M-K, Park KS, Bae YH, Yun J, Park J-I, Kwak J-Y, Bae Y-S: Serum amyloid A stimulates matrix-metalloproteinase- 9 upregulation via formyl 
peptide receptor like-1-mediated signaling in human monocytic cells. Biochem Bioph Res Co 2005, 330:989-998.

54. He RL, Zhou J, Hanson CZ, Chen J, Cheng N, Ye RD: Serum amyloid A induces G-CSF expression and neutrophilia via Toll-like receptor 2. Blood 2009, 113:429-437.

55. Tamzali Y, Guelfi JF, Braun JP: Plasma fibrinogen measurement in the horse: comparison of Millar's technique with a chronometric technique and the QBC-Vet Autoreader. Res Vet Sci 2001, 71:213-217.

56. Ganheim C, Hulten C, Carlsson U, Kindahl H, Niskanen R, Waller KP: The acute phase response in calves experimentally infected with bovine viral diarrhoea virus and/or Mannheimia haemolytica. J Vet Med B Infect Dis Vet Publ Health 2003, 50:183-190.

57. Yamada M, Murakami K, Wallingford JC, Yuki Y: Identification of lowabundance proteins of bovine colostral and mature milk using twodimensional electrophoresis followed by microsequencing and mass spectrometry. Electrophoresis 2002, 23:1153-1160.

58. Ugarova TP, Yakubenko VP: Recognition of fibrinogen by leukocyte integrins. Ann NY Acad Sci 2001, 936:368-385.

59. Ryu JK, Davalos D, Akassoglou K: Fibrinogen signal transduction in the nervous system. J Thromb Haemost 2009, 7:151-154.

60. Kuhns DB, Nelson EL, Alvord WG, Gallin J: Fibrinogen induces IL-8 synthesis in human neutrophils stimulated with formyl-methionyl-leucyl-phenylalanine or leukotriene B(4). J Immunol 2001, 167:2869-2878.

61. Piñan DFO: Guia de Campo de las Razas Autóctonas Españolas. ; 2010.

62. Jarrige R: Alimentation Des Bovins. Inra-Quae: Ovins \& Caprins; 1988.

63. Castro N, Capote J, Morales L, Quesada E, Briggs H, Arguello A: Short communication: addition of milk replacer to colostrum whey: effect on immunoglobulin G passive transfer in Majorera kids. J Dairy Sci 2007, 90:2347-2349.

64. Almeida AM, Campos A, Francisco R, van Harten S, Cardoso LA, Coelho AV: Proteomic investigation of the effects of weight loss in the gastrocnemius muscle of wild and NZW rabbits via 2D-electrophoresis and MALDI-TOF MS. Anim Genet 2010, 41:260-272.

65. Marcelino I, de Almeida AM, Ventosa M, Pruneau L, Meyer DF, Martinez D, Lefrancois T, Vachiery N, Coelho AV: Tick-borne diseases in cattle: Applications of proteomics to develop new generation vaccines. J Proteomics 2012, 75:4232-4250.

doi:10.1186/1746-6148-10-85

Cite this article as: Hernández-Castellano et al: The effect of colostrum intake on blood plasma proteome profile in newborn lambs: low abundance proteins. BMC Veterinary Research 2014 10:85.

\section{Submit your next manuscript to BioMed Central and take full advantage of:}

- Convenient online submission

- Thorough peer review

- No space constraints or color figure charges

- Immediate publication on acceptance

- Inclusion in PubMed, CAS, Scopus and Google Scholar

- Research which is freely available for redistribution

Submit your manuscript at www.biomedcentral.com/submit
(O) Biomed Central 